\title{
Study on the Dialectical Relationship between New Media Information Resources and Ideological and Political Education*
}

\author{
Bing $\mathrm{He}$ \\ College of Marxism \\ Heihe University \\ Heihe, China 164300
}

\begin{abstract}
The application of new media information resources in ideological and political education has become an important educational method and content. In order to improve the efficiency of ideological and political education and give full play to the utilization of new media information resources, the key lies in the full grasp and flexible use of the dialectical relationship between the information resources of the new media and the ideological and political education. Based on the dialectical relationship between the new media information resources and the ideological and political education, this paper puts forward that the utilization of the new media information resources and the efficiency of the ideological and political education can be maximized by the unity of the two in the same identity and in the struggle. And then the expected effect and purpose of the ideological and political education can be achieved.
\end{abstract}

Keywords-new media information resources; ideological and political education; dialectical relationship

\section{INTRODUCTION}

With the advent of the big data era, the new media information resources are pervasively influencing and shaping people's ideas and values. With its new, extraordinary and special characteristics, new media information resources make college students have a strong curiosity for various new media information resources. However, due to their limited social experience, college students can't distinguish the truth of various resources false. The utilization rate of new media information resources in the ideological and political education of college students self-learning process has not been better played. It also requires the college students to maximize the utilization of new media information resources and the efficiency of ideological and political education in the process of ideological and political education. It also asks the college students to handle the dialectical relationship between new media information resources and ideological and political education. The dialectical relationship between new media

*Fund Project: Philosophy and Social Sciences Research Project in Heilongjiang province: Research on the Relationship between the Utilization of Information Resources and the Efficiency of Ideological and Political Education in Colleges and Universities in the Big Data Era (16KSC04) information resources and ideological and political education is also dialectical relationship between the two concepts in the same struggle. It proposes that two concepts should be united in the sameness and be unified in the struggle. And finally, the utilization rate of new media information resources and the efficiency of ideological and political education should be maximized.

\section{INTERPRETATION ON THE IDENTITY OF NEW MEDIA INFORMATION RESOURCES AND IDEOLOGICAL AND POLITICAL EDUCATION}

The identity of new media information resources and ideological and political education refers to the interdependence, mutual penetration and interpenetration of functions, goals, concepts, and functions between the new media information resources and ideological and political education.

\section{A. The Functional Interoperability of New Media Information Resources and Ideological and Political Education - Bearing Education Dissemination}

The fundamental task of ideological and political education is "to strengthen moral education and cultivate people". It is related to the question of cultivating the students. Through the ideological and political education, it is necessary to train the undergraduates to establish a correct world outlook, values and outlook on life. And then, the college students would have good ideological and moral qualities and political literacy. The new media information resources are various in forms. They are a collection of all kinds of information activities. They have the task of carrying information and disseminating information. They also have the task of educating college students on values and ideological and political concepts. Thus, the new media information resources are related to ideological and political education in the function. And they carry the role of spreading the education. 


\section{B. The Consistency on the Target of New Media} Information Resources and Ideological and Political Education - To Pay Attention to Spiritual Needs

The report of the 19th NPC pointed out: "The major contradictions in Chinese society have been transformed into the contradictions between the growing needs of a better life and unbalanced development." In other words, people pay more and more attention to their own spiritual needs. The goal of ideological and political education is to help college students to establish their lofty ideals and beliefs, to pursue their high level of interest and to meet the needs of the students in a positive, lively and healthy spirit. They are worthy of the demands of the times and the hopes of the community. The new media information resources are entertaining, popular and diverse. The characteristics would meet the pursuit of new, strange, special, and other intellectual needs and new spiritual needs. It can be seen that the new media information resources and ideological and political education have satisfied the spiritual needs of college students in different degrees. And they have consistent goals.

\section{The Corresponding Nature of New Media Information Resources and Ideological and Political Education - Following the Principle of People First}

Ideological and political education of college students always adhere to the concept of people first. And the students would be as an educatee. In the process of education, we must be in accordance with the requirements of the main students and the main fact. It could give full play to students' ability to learn independently and the inherent potential. And then, it would achieve the concept of people first. The new media information resources are social sharing of resources. The audiences are equal. Every member of the community can independently choose new media information resources. And they will not be subject to any different status restrictions. It leaves a lot of space for creativity and choice for the audience. The new media information resources and ideological and political education embodies the concept of people first and corresponding nature in different breadth and depth.

\section{The Similarity in the Function of New Media \\ Information Resources and Ideological and Political Education - the Influence on Ideological Concepts}

The ideological and political education of undergraduates mainly helps the undergraduates establish a correct outlook on life, values and world outlook through the main channels of ideological and political theory course and the main position of daily ideological and political education. It can help college students persist in themselves after rejecting the society and abandon bad social ethos and false political thoughts. It is of great practical significance. And it may affect the ideological concepts of college students. The information resources of new media have strong permeation and universality. It can influence the study, life and various activities of college students. And it can make college students change the value, ideology, thinking mode and behavior standard in unnoticed process. They are the social sharing educational resources that affect college students' ideology. Therefore, the new media information resources and ideological and political education have certain similarity in the function.

\section{THE INTERPRETATION ON FIGHTING SPIRIT OF NEW MEDIA INFORMATION RESOURCES AND IDEOLOGICAL AND POLITICAL EDUCATION}

The struggle between new media information resources and ideological and political education refers to the mutually exclusive and conflicting nature of new media information resources and ideological and political education. It mainly shows the contradiction and the conflict in the ideology and the contradiction and the conflict in the fragmentation and the classics, the spontaneity and the instillation.

\section{A. The Ideological Contradictions and Conflicts in New Media Information Resources and Ideological and Political Education}

From the perspective of the goal of high education in China, Article 5 of the Education Law of the People's Republic of China stipulates: "We must implement the educational policy of the state, serve the construction of socialist modernization, combine production and labor, and enable the educatee to become builders and successors of the socialist cause of all-round development, such as morality, wisdom and physique." Among them, morality refers to the ideological and moral character of the students. And the idea of "serving the construction of socialist modernization" is the embodiment of the ideological will of the ruling class. Therefore, carrying out ideological and political education widely in colleges and universities, enabling the educated to possess excellent ideological and moral character and correct political consciousness is the purpose of higher education in China. It has distinct ideological and political characteristics. New media information resources have the characteristics of entertainment, consumption and fragmentation. And their political ideas and beliefs are not strong. It would lead the audience to pay attention to sensory enjoyment and material consumption. The audience groups have full freedom of choice. As long as the audience groups are willing, the choices of what kind of ideology of new media information resources are not important. In this case, the socialist ideology has been gradually marginalized, digested and covered. Therefore, the new media information resources and ideological and political education have ideological contradiction and conflict.

\section{B. The Conflict between the Fragmentation of New Media Information Resources and the Classicalization of Ideological and Political Education}

Ideological and political theory education advocates classics. Especially, the "Introduction to the Fundamentals of Marxism," "An Introduction to Mao Zedong Thought and the Theoretical System of Socialism with Chinese Characteristics," "The Socialist Core Values," "The Spirit of China" and" Moral requirements " has proved the scientific theory and ideological achievements. It has far-reaching and lasting effects on the development of human society and the 
physical and mental health of individuals. The new media information resources refer to the kind of leisure entertainment and secular culture resources. It can be disseminated to the audiences in various forms, such as microblogging, circle of friends, and short video. It is a kind of lively and fragmentary culture and new media information resources. The university student can produce the temporarily joyful and the immediate emotion resonance. The happiness and the emotion resonance is one kind of brief emotion. It cannot withstand the long time ponder and the lasting thought. Therefore, there are contradictions and conflicts between the information resources of new media and the ideological and political education.

\section{Contradiction and Conflict between Spontaneity of New Media Information Resources and Indoctrination of Ideological and Political Education}

Under the guidance of the pattern of great thought and politics, ideological and political education emphasizes that college students mainly receive the education in the classroom, position edifies outside the classroom, social practice exercise and so on. The specific personnel (such as the teacher, the counselor) instill the relatively fixed ideological and political content to the university student in the fixed place (the classroom, the practice base) and the fixed time (the classroom, the practice, the student activity). The way and content of its dissemination of new media information resources in various forms are more in line with the psychological acceptance requirements of college students. Compared with the content of ideological and political education in the university, the level of seriousness is relatively low. And the way of communication is very convenient. The mobile phone or other new media can complete the dissemination of information resources without any restrictions on personnel, time and location. College students unconsciously and spontaneously accept and recognize it. In contrast, students prefer the spontaneity and convenience of new media information resources. With the same degree, they would resist the instillation of ideological and political education. Therefore, the new media information resources and ideological and political education have ideological contradiction and conflict.

\section{APPLICATION OF DIALECTICAL RELATIONSHIP BETWEEN NEW MEDIA INFORMATION RESOURCES AND IDEOLOGICAL AND POLITICAL EDUCATION}

The two essential attributes of identity and struggle are mutually linked and indivisible. And they cannot act in isolation in the development of things. The flexible use of the dialectical relationship between the new media information resources and the ideological and political education is beneficial to the improvement of the efficiency of the ideological education and the healthy development and utilization of the new media information resources. And then, it is helpful to create a win-win situation between the new media information resources and the ideological and political education.

\section{A. New Media Information Resources and Ideological and Political Education Are Communicative in the Sameness}

The identity of contradiction plays an important role in the development of things. First, the two sides of the contradiction depend on each other to keep the relative stability of things. And it is to provide the necessary premise for the existence and development of things. Second, the two sides of the contradiction learn from each other to benefit their own factors to be developed. Third, the identity of contradictions defines the basic trend of the transformation of things to the opposite. The information resources of new media are identical with the ideological and political education in function, goal and idea. On the one hand, these identities provide the premise for the existence and development of media information resources and ideological and political education. On the other hand, these identities provide the condition for the mutual reference of media information resources and ideological and political education. The two sides can find common ground in terms of functions, objectives and concepts. And then, they would seek common ground while reserving differences. With the premise of the identity of new media information resources and ideological and political education, they would mutually absorb the factors conducive to their own development. And then, they would achieve mutual integration and common improvement.

\section{B. The Unity of New Media Information Resources and Ideological and Political Education in the Struggle}

The conflict of contradiction plays an important role in the development of things. First, in the process of quantitative change of things, the struggles promote the two sides of the contradiction to make the changes. And it prepares for qualitative change. Second, in the process of qualitative changes of things, the struggle would break through the limits of things, promote the transformation of contradictions, and achieve the qualitative changes of things. In short, the conflict of contradiction drives things to change quantitatively. The contradictions and conflicts between information resources of new media and ideological and political education in ideology, as well as the contradictions and conflicts between fragmentation and classicalization, spontaneity and instillation, will certainly bring about corresponding changes in their respective positions and functions in the struggle. As for the result of the struggle, we should merge each other into a pair of new paradigms. It should strive to form the ideological and political education of college students in the process of selecting effective new media information resources. Also, it should improve the use of new media information resources and ideological and political education efficiency.

\section{CONCLUSION}

In short, firstly, the dialectical relationship between the new media information resources and the ideological and political education should be correctly recognized. Secondly, the dialectical relationship of the two should be fully grasped. Then, we could fundamentally improve the utilization rate of new media information resources and the efficiency of ideological and political education. It may realize the due 
effect and expected goal of the utilization of the new media information resources and the ideological and political education. It should fully grasp and make flexible use of new media information resources, and innovate educational methods based on the use of new media information resources. Then, it should fundamentally reform the traditional ideological and political education methods. And then, the college students can easily accept it. The efficiency of ideological and political education will further achieve the expected educational effect and purpose.

\section{REFERENCES}

[1] Xi Jinping. Decision to build a well-off society in an all-round way to win the great victory of socialism with Chinese characteristics in the new era [N] People's Daily, 2017-10-28 (01).

[2] Zhang Weijuan. The same struggle [D]. Jilin University, 2009. 